\title{
Aliskiren and valsartan combination therapy for the management of hypertension
}

\author{
This article was published in the following Dove Press journal: \\ Vascular Health and Risk Management \\ 10 August 2010 \\ Number of times this article has been viewed
}

\section{Benjamin J Epstein \\ Departments of Pharmacotherapy and Translational Research and Medicine, Colleges of Pharmacy and Medicine, University of Florida, Gainesville, Florida, USA and East Coast Institute for Research, Jacksonville, Florida, USA}

Correspondence: Benjamin J Epstein Departments of Pharmacotherapy and Translational Research and Medicine, Colleges of Pharmacy and Medicine, University of Florida, Gainesville, FL 32610-0486, USA

$\mathrm{Tel}+\mathrm{I}$ (352) 273-6232

Fax +I (352) 273-6242

Email epstein@cop.ufl.edu

\begin{abstract}
Combination therapy is necessary for most patients with hypertension, and agents that inhibit the renin-angiotensin-aldosterone system (RAAS) are mainstays in hypertension management, especially for patients at high cardiovascular and renal risk. Single blockade of the RAAS with an angiotensin-converting enzyme (ACE) inhibitor or angiotensin receptor blocker (ARB) confers some cardiorenal protection; however, these agents do not extinguish the RAAS as evidenced by a reactive increase in plasma renin activity (PRA), a cardiovascular risk marker, and incomplete cardiorenal protection. Dual blockade with an ACE inhibitor and an ARB offers no additional benefit in patients with hypertension and normal renal and left ventricular function. Indeed, PRA increases synergistically with dual blockade. Aliskiren, the first direct renin inhibitor (DRI) to become available has provided an opportunity to study the merit of DRI/ARB combination treatment. By blocking the first and rate-limiting step in the RAAS, aliskiren reduces PRA by at least $70 \%$ and buffers the compensatory increase in PRA observed with ACE inhibitors and ARBs. The combination of a DRI and an ARB or an ACE inhibitor is an effective approach for lowering blood pressure; available data indicate that such combinations favorably affect proteinuria, left ventricular mass index, and brain natriuretic peptide in patients with albuminuria, left ventricular hypertrophy, and heart failure, respectively. Ongoing outcome studies will clarify the role of aliskiren and aliskiren-based combination RAAS blockade in patients with hypertension and those at high cardiorenal risk.
\end{abstract}

Keywords: aliskiren, valsartan, single-pill combination, hypertension, renin-angiotensinaldosterone system, plasma renin activity

Hypertension is a progressive condition with significant health consequences. ${ }^{1}$ Even slight elevations (ie, $2 \mathrm{mmHg}$ ) in blood pressure (BP) can substantially increase cardiovascular and cerebrovascular risk. ${ }^{2,3}$ The ultimate goal of treating hypertension is to achieve and maintain a BP that will optimally reduce the risk for cardiovascular, cerebrovascular, and renal disease and death. ${ }^{4,5}$ However, obtaining and maintaining adequate control of BP can be a challenge for many high-risk patients. According to the US National Health and Nutrition Examination Survey (NHANES), BP is effectively controlled in less than $40 \%$ of patients receiving antihypertensive therapy; patients with diabetes or cardiovascular, cerebrovascular, or renal disease fare even worse, exhibiting lower BP control rates than do patients without these comorbidities. ${ }^{6,7}$ These observations suggest that more effective treatment strategies are needed for physicians to help patients achieve BP goals and, ultimately, to reduce hypertensionrelated disease and death.

Evidence continues to accumulate from landmark randomized trials showing the need for at least two antihypertensive agents to successfully treat hypertension in most 
patients. For example, in the ALLHAT trial, $63 \%$ of patients with hypertension and at least one additional cardiovascular risk factor required at least two antihypertensives to achieve a BP goal of $<140 / 90 \mathrm{mmHg}$ after 4.9 years of follow-up. ${ }^{8}$ In the ASCOT-BPLA trial, which included more than 19,000 patients with hypertension and at least three additional cardiovascular risk factors, $78 \%$ of patients required treatment with at least two antihypertensive agents to maintain the target BP $(<140 / 90 \mathrm{mmHg}$ for patients without diabetes; $<130 / 80 \mathrm{mmHg}$ for patients with diabetes). ${ }^{9}$ In AASK, an average of three agents were needed to achieve a mean arterial pressure goal of $\leq 92 \mathrm{mmHg} .{ }^{10}$ Because combination treatment is eventually necessary, published guidelines recommend it as initial treatment for most patients, especially those with initial high BP and those with cardiovascular or renal risk. ${ }^{4,511}$ This approach also allows patients to achieve the BP goal more quickly. In the ACCOMPLISH trial, in which 11,506 patients with high risk for hypertension were randomly assigned to receive combination therapy, $73 \%$ of patients were able to achieve BP control within 6 months. ${ }^{12,13}$

It is expected that prompt control of BP will discourage therapeutic inertia and might improve outcomes in patients with hypertension; however, few studies have been aimed at evaluating the relationship of attainment of early BP control with cardiovascular outcomes. The VALUE trial enrolled patients with hypertension and a history of cardiovascular disease, diabetes, or stroke. Attainment of BP control (systolic $\mathrm{BP} \leq 140 \mathrm{mmHg}$ ) within 6 months was associated with a significant reduction in the risk for cardiovascular events and death, regardless of the type of drug used. ${ }^{14}$ Furthermore, in the ASCOT trial, relative to those receiving an atenolol-based combination therapy regimen, hypertensive patients receiving an amlodipine-based regimen exhibited a significant reduction in the total number of coronary events associated with superior BP control, which was evident by 1 year of treatment. ${ }^{9}$ Finally, the Syst-EUR trial found that, compared with delayed treatment and control, early treatment and control of BP in hypertensive adults 60 years or older resulted in a significant reduction in the frequency of, and risk (adjusted relative hazard) for, stroke and major cardiovascular events. ${ }^{15}$ In this study, delayed onset of antihypertensive treatment also showed benefit in clinical outcomes by reduction of systolic BP in patients, albeit to a lesser extent than in the early-treatment group. The soon-to-be-released Joint Commission (JNC-8) recommendations are expected to further highlight the importance of the use of combination therapy early in the hypertension treatment algorithm.
Contemporary evidence from the studies noted herein will be incorporated into the updated guidelines as further evidence of the value of logical combination therapy for securing more effective and earlier BP control and improved outcomes. Combinations that include a renin-angiotensin-aldosterone system (RAAS) antagonist, such as an angiotensin-converting enzyme (ACE) inhibitor or an angiotensin receptor blocker (ARB), plus a calcium channel blocker or thiazide diuretic are the most effective, well-tolerated, and proven strategies. ${ }^{11}$

\section{The role of the RAAS in hypertension management}

The role of the RAAS in cardiovascular and renal homeostasis is well established, as is the role of an up-regulated RAAS in cardiovascular disease such as hypertension and ischemic heart disease ${ }^{16}$ Angiotensin II, the major effector peptide of the RAAS, contributes to the progression of target organ damage via a number of hemodynamic and cellular actions (Figure 1). By promoting vasoconstriction and aldosterone release and by increasing oxidative stress, as well as augmenting the production of cytokines, adhesion molecules, and growth factor in these target tissues, angiotensin II plays a pivotal role in cardiovascular and renal disease. Some of the other pathologic effects of angiotensin II include cardiac and vascular remodeling, inflammation, thrombosis, and even plaque rupture, the ultimate and lethal step in atherosclerosis. ${ }^{17}$ With regard to renal disease, angiotensin II is partially responsible for promoting albuminuria and accelerating the decrease in the glomerular filtration rate associated with diabetic nephropathy, the leading cause of end-stage renal disease in the modern world. ${ }^{18}$ Inhibitors of RAAS, such as ARBs, and, more recently, the direct renin inhibitor aliskiren, alone and in combination with an ARB, has been shown to slow the decrease in glomerular filtration rate and diminish albuminuria in patients with diabetic nephropathy. ${ }^{19,20}$ In addition to angiotensin II, other RAAS components have been cited as biomarkers of cardiovascular risk. Elevated levels of plasma renin activity (PRA) have been shown to be independently associated with an increased risk for myocardial infarction (MI) in patients with hypertension. ${ }^{21}$ More recently, in an analysis of 2913 patients with stable vascular disease or diabetes who were enrolled in the HOPE study, an elevated PRA was found to be associated with a $49 \%$ increase in the risk for major cardiovascular events. ${ }^{22}$ In 1172 patients with severe coronary artery disease with no history of cardiac events, elevated PRA independently predicted a $40 \%$ increased risk for death and a twofold increased risk for hospitalization for congestive heart failure 


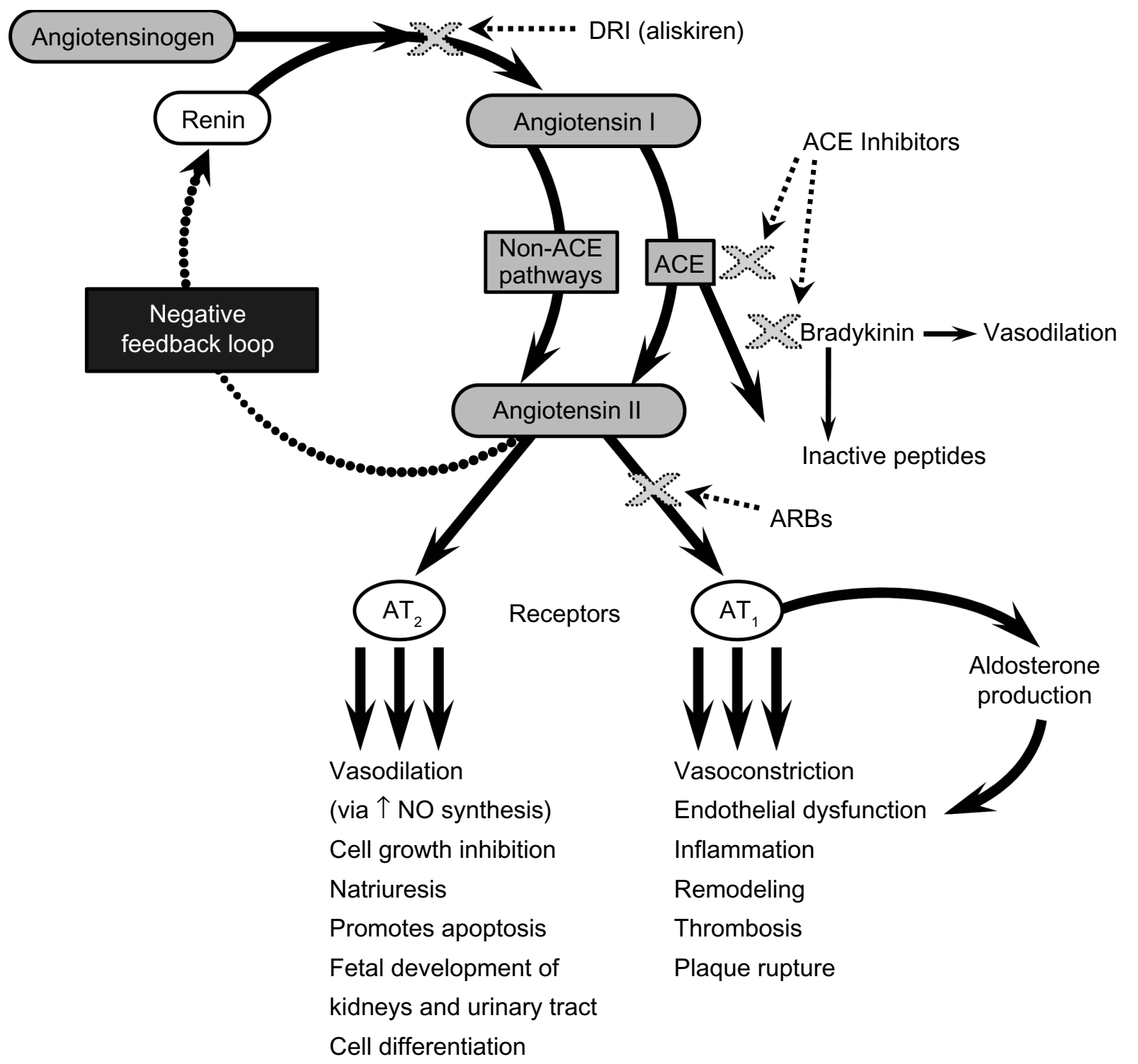

Figure I The renin-angiotensin-aldosterone system.

Abbreviations: DRI, direct renin inhibitor; ACE, angiotensin-converting enzyme; ARB, angiotensin receptor blocker; AT, angiotensin II receptor, type I/2; NO, nitric oxide.

(CHF) during long-term ( $>5$ years) follow-up. ${ }^{23}$ Evidence is also accumulating that the overproduction of aldosterone increases cardiovascular risk independent of its effects on $\mathrm{BP}$, and, similar to angiotensin II, promotes inflammation, oxidative stress, and fibrosis. ${ }^{24}$

Although pharmacologic manipulation of the RAAS with ACE inhibitors and ARBs improves outcomes in hypertension and cardiovascular and renal disease, it provides only partial protection from disease progression (Table 1). This might be explained by the contributions of other mechanisms to disease or progression or by the inadequacy of ACE inhibitors and ARBs. Possible mechanisms for the inadequacies include interruption of negative feedback and a compensatory increase in renin and angiotensin
I levels, which can overcome ACE inhibition or result in the production of angiotensin II by non-ACE pathways (ie, ACE escape).$^{25}$ Further, the inability of ARBs to occupy all angiotensin II type (AT), receptors at any given time ${ }^{26}$ and aldosterone breakthrough ${ }^{27,28}$ during ACE inhibition or ARB use are additional possible mechanisms for this lack of complete protection by ACE inhibition and angiotensin receptor blockade. For these reasons, inhibition of renin (the first and rate-limiting step in the RAAS; Figure 1) has long been a pharmacologic target for RAAS blockade; however, only recently has aliskiren emerged as the first direct renin inhibitor (DRI) available for clinical use. ${ }^{29}$ By inhibiting the conversion of angiotensinogen to angiotensin I and by decreasing PRA, aliskiren may provide a more complete 


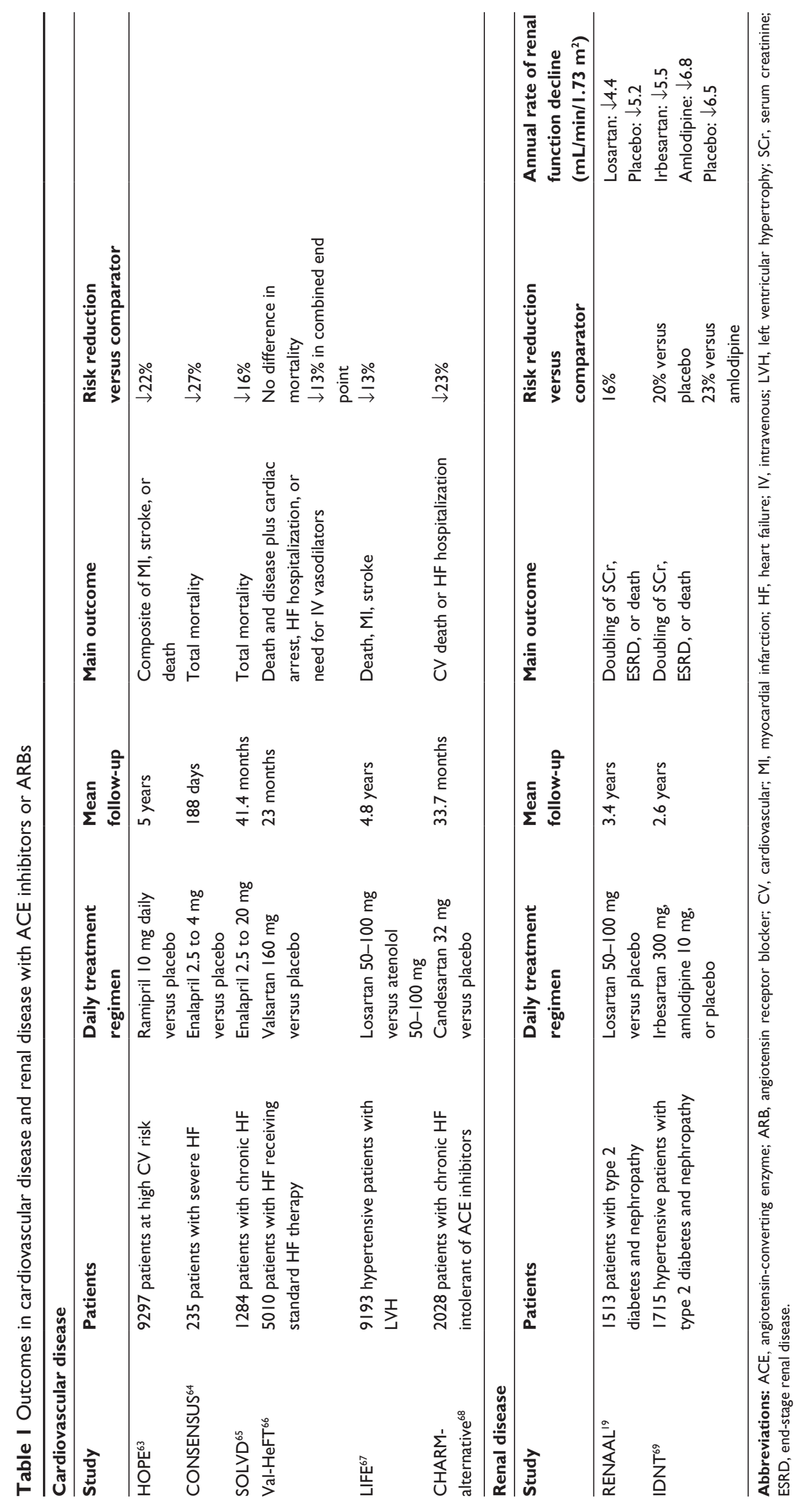


blockade of the RAAS and offers a new opportunity to explore multistep RAAS blockade.

The remainder of this article is directed at evaluating the experience accumulated with combination DRI/ACE or ARB, discussing the differences between dual RAAS blockade with ACE inhibitors/ARBs and DRI plus an ACE inhibitor or an ARB, and reviewing the role of combination aliskiren/ valsartan in the treatment of hypertension.

\section{Dual RAAS blockade ACE inhibitor plus ARB}

The success of single RAAS blockade with an ACE inhibitor or an ARB led researchers to theorize that dual RAAS blockade might confer an even greater benefit on BP lowering and cardiorenal outcomes. Unfortunately, this has not been consistently demonstrated. Combining an ACE inhibitor and an ARB produces only small, incremental reductions in BP. In a meta-analysis of randomized controlled trials in which $\mathrm{ACE}$ inhibitors and ARBs were administered in combination for the treatment of hypertension (defined as a sitting systolic $\mathrm{BP}[\mathrm{SBP}] \geq 140 \mathrm{mmHg}$ and/or diastolic BP $[\mathrm{DBP}] \geq 90 \mathrm{mmHg}$; mean ambulatory SBP or DBP of $\geq 130 \mathrm{mmHg}$ or $85 \mathrm{mmHg}$, respectively; or use of antihypertensive agents), ambulatory SBP/DBP was reduced overall by $4.7 / 3.0 \mathrm{mmHg}$, compared with ACE inhibitor monotherapy, and by $3.8 / 2.9 \mathrm{mmHg}$, compared with ARB monotherapy.$^{30}$ Reductions in sitting SBP/DBP relative to ACE inhibitor or ARB monotherapy were $3.8 / 2.7 \mathrm{mmHg}$ and $3.7 / 2.3 \mathrm{mmHg}$, respectively. Surrogate end point and outcome studies have not consistently shown clinical benefits of ACE inhibitor/ARB combination therapy compared with respective monotherapies (Table 2). Most recently, ONTARGET, the largest of these studies, determined that combining the ACE inhibitor ramipril with the ARB telmisartan did not provide high-risk patients who have hypertension with any additional cardiovascular protection than an ACE inhibitor or an ARB alone..$^{31,32}$ These results were unexpected and suggest that administration of an ACE inhibitor plus an ARB may not be optimal for blocking RAAS in patients with hypertension but without left ventricular dysfunction or kidney disease. Consequently, this approach should not be routinely prescribed for such patients.

It is not clear why combination RAAS blockade was unsuccessful in ONTARGET; however, several mechanisms are worthy of consideration. Perhaps single-step RAAS blockade sufficiently diminishes the deleterious effects of RAAS so that further blockade does not provide a measurable clinical benefit in this population. This does not seem likely because ACE inhibitors and ARBs do not fully extinguish overactive RAAS activity in high-risk patients and because higher doses of ACE inhibitors and ARBs have been shown to improve outcomes ${ }^{33,34}$ It could also be that the population enrolled in ONTARGET was well treated at baseline, resulting in a low event rate, which would require longer follow-up or a higher risk population for the benefit to be detected. The findings might also be inherent to the combination of an ACE inhibitor and an ARB. The combination did not markedly lower BP, compared with the single RAAS agent regimens. Additionally, combination ACE inhibitor/ARB treatment potentiates an exponential increase in PRA, which could further drive ACE and aldosterone escape pathways (Figure 1).

Although the combination of an ACE inhibitor and an ARB interrupts two important steps in the RAAS pathway, it does not interfere with the rate-limiting step in the pathway: the conversion of angiotensinogen to angiotensin I by renin. Several studies have underscored the importance of this step, measured as PRA, in predicting the risk for cardiovascular events. In the SAVE trial, in patients with acute MI, two neurohormones (PRA and atrial natriuretic peptide) were independently predictive of future cardiovascular disease (assessed by multivariate analysis) ${ }^{35}$ Elevated PRA at the time of hospital discharge for acute MI was associated with a $60 \%$ increased risk for total cardiovascular disease and a 100\% increased risk for severe heart failure. In the Val-HeFT study, higher baseline PRA was associated with increased rates of morbidity and mortality in patients with stable moderate to severe heart failure. ${ }^{36}$ Whether the introduction of an RAAS antagonist, such as aliskiren, that reduces PRA levels is capable of offering greater cardioprotection is a question that has only recently been entertained.

\section{Aliskiren plus ACE inhibitor or ARB}

Researchers have shown that additional reductions in BP can be achieved when aliskiren is combined with an ACE inhibitor or an ARB. ${ }^{37,38}$ In pilot studies, the addition of aliskiren $150 \mathrm{mg}$ once daily to ramipril $5 \mathrm{mg}$ once daily for 3 weeks lowered ambulatory daytime and nighttime SBP an additional 7 to $8 \mathrm{mmHg}$; when added to once-daily irbesar$\tan 150 \mathrm{mg}$, aliskiren reduced daytime SBP an additional $1.9 \mathrm{mmHg}$ and nighttime SBP an additional $4.2 \mathrm{mmHg} .{ }^{37}$ In another study, oncedaily aliskiren $150 \mathrm{mg} /$ ramipril oncedaily $10 \mathrm{mg}$ for 8 weeks reduced mean sitting SBP/DBP by an additional $4.6 / 2.1 \mathrm{mmHg}$, compared with ramipril 
Table 2 Outcome studies that included combination treatment with ACE inhibitors and ARBs

\begin{tabular}{|c|c|c|c|c|c|}
\hline \multicolumn{6}{|c|}{ Cardiovascular disease } \\
\hline Study & Patients & $\begin{array}{l}\text { Daily treatment } \\
\text { regimen }\end{array}$ & $\begin{array}{l}\text { Mean follow- } \\
\text { up }\end{array}$ & Main outcome & $\begin{array}{l}\text { Main findings with combination } \\
\text { therapy }\end{array}$ \\
\hline VALIANT ${ }^{70}$ & $\begin{array}{l}4909 \\
4909 \\
4885 \\
\text { Acute MI patients } \\
\text { with HF/LVD }\end{array}$ & $\begin{array}{l}\text { Valsartan } \\
\text { Captopril } \\
\text { Both }\end{array}$ & 24.7 months & Death & $\begin{array}{l}\text { Combination did not improve survival } \\
\text { relative to either monotherapy ( } 19 \%- \\
20 \% \text { in each group died) or other key } \\
\text { secondary outcomes despite additional } \\
\text { BP lowering. The combination group } \\
\text { experienced more AEs than either } \\
\text { monotherapy group }\end{array}$ \\
\hline $\begin{array}{l}\text { CHARM- } \\
\text { added }^{71}\end{array}$ & $\begin{array}{l}2548 \text { patients with } \\
\text { HF and LVD receiving } \\
\text { ACE inhibitor }\end{array}$ & $\begin{array}{l}\text { Candesartan or } \\
\text { placebo }\end{array}$ & 41 months & $\begin{array}{l}\mathrm{CV} \text { death or HF } \\
\text { hospitalization }\end{array}$ & $\begin{array}{l}\text { Outcomes experienced by } 42 \% \text { of } \\
\text { patients in placebo group and } 38 \% \\
\text { in candesartan group }(P=0.01 \mathrm{I}) \text {. } \\
\text { Combination produced larger BP } \\
\text { reductions but caused more patients } \\
\text { to discontinue treatment for AEs ( } 24 \% \\
\text { versus } 18 \% ; P=0.0003)\end{array}$ \\
\hline Val-HeFT ${ }^{66}$ & $\begin{array}{l}50 \mathrm{I} 0 \text { patients } \\
\text { with } \mathrm{HF}\end{array}$ & $\begin{array}{l}\text { Valsartan } 160 \mathrm{mg} \\
\text { vs placebo }\end{array}$ & 23 months & $\begin{array}{l}\text { Death and death } \\
\text { plus cardiac arrest, } \\
\text { HF hospitalization, } \\
\text { or need for } \\
\text { vasodilators }\end{array}$ & $\begin{array}{l}\text { Among the } 366 \text { patients who were } \\
\text { receiving an ACE inhibitor plus a } \\
\beta \text {-blocker, valsartan adversely affected } \\
\text { total risk of death; among the } 366 \text { patients } \\
\text { not receiving an ACE inhibitor, valsartan } \\
\downarrow \text { risk for death } 33 \% \text { and composite } \\
\text { end point } 44 \% \text { (versus } 0 \% \text { and } \downarrow 13 \% \text { for } \\
\text { combined valsartan/ACE inhibitor) }\end{array}$ \\
\hline ONTARGET ${ }^{31}$ & $\begin{array}{l}8576 \\
8542 \\
8502 \\
\text { Patients with vascular } \\
\text { disease or high-risk } \\
\text { diabetes without } \mathrm{HF}\end{array}$ & $\begin{array}{l}\text { Ramipril } 10 \mathrm{mg} \\
\text { Telmisartan } 80 \mathrm{mg} \\
\text { Both }\end{array}$ & 56 months & $\begin{array}{l}\text { Composite of CV } \\
\text { death, MI, stroke, } \\
\text { or HF } \\
\text { hospitalization }\end{array}$ & $\begin{array}{l}\text { Primary outcome occurred to a similar } \\
\text { degree in each group }(16.3 \%-16.7 \% \\
\text { patients) } \\
\text { Compared with ramipril, greater rates of } \\
\text { hypotensive symptoms with combination } \\
(4.8 \%)(I .7 \% ; P<0.00 I) \text { and renal } \\
\text { dysfunction }(I 3.5 \% \text { versus } 10.2 \% ; P<0.00 I)\end{array}$ \\
\hline \multicolumn{6}{|c|}{ Renal outcomes } \\
\hline CALM $^{72}$ & $\begin{array}{l}199 \text { patients with } \\
\text { hypertension, type } 2 \\
\text { diabetes, and MAU }\end{array}$ & $\begin{array}{l}\text { Candesartan or } \\
\text { lisinopril, followed } \\
\text { by candesartan, } \\
\text { lisinopril, or the } \\
\text { combination }\end{array}$ & 12 weeks & $\begin{array}{l}\text { Change in } \\
\text { UACR and BP }\end{array}$ & $\begin{array}{l}\text { UACR reduced } 50 \% \text { with combination, } \\
24 \% \text { with candesartan, and } 39 \% \text { with } \\
\text { lisinopril }(P=0.04 \text { for combination vs } \\
\text { candesartan and }>0.20 \text { versus lisinopril BP } \\
\text { reduced } 25.3 / 16.3,14.1 / I 0.4 \text {, and } 16.7 / \\
10.7 \mathrm{mmHg} \text { with combination, candesartan } \\
\text { and lisinopril ( } P \leq 0.005 \text { for either } \\
\text { monotherapy versus combination) }\end{array}$ \\
\hline IMPROVE ${ }^{73}$ & $\begin{array}{l}405 \text { hypertensive, } \\
\text { high risk CV } \\
\text { patients with MAU }\end{array}$ & $\begin{array}{l}\text { Ramipril plus } \\
\text { irbesartan } \\
\text { Ramipril plus } \\
\text { placebo }\end{array}$ & 20 weeks & Change in UAER & $\begin{array}{l}\text { UAER reduced } 46 \% \text { with combination } \\
\text { versus } 42 \% \text { with ramipril/placebo; } \\
P=0.540 \\
\text { AEs similar between groups }\end{array}$ \\
\hline ONTARGET 32 & $\begin{array}{l}8576 \\
8542 \\
8502\end{array}$ & $\begin{array}{l}\text { Ramipril } 10 \mathrm{mg} \\
\text { Telmisartan } 80 \mathrm{mg} \\
\text { Both }\end{array}$ & 56 months & $\begin{array}{l}\text { Composite renal } \\
\text { outcome of } \\
\text { doubling of } \mathrm{SCr} \text {, } \\
\text { ESRD, or death }\end{array}$ & $\begin{array}{l}\text { Main outcome occurred most frequently } \\
\text { with combination }(14.5 \% ; P=0.037) \\
\text { versus } 13.4 \% \text { with telmisartan and } 13.5 \% \\
\text { with ramipril } \\
\text { eGFR decrease }\left(\mathrm{mL} / \mathrm{min} / 1.73 \mathrm{~m}^{2}\right) \text { : } \\
\text { ramipril, }-2.82 ; \text { telmisartan, }-4.12 \text {; } \\
\text { combination, }-6.1 \mathrm{I} ;(P<0.00 \mathrm{I} \\
\text { comparisons with ramipril) } \\
\text { Worse outcomes despite reduced } \\
\text { proteinuria with combination therapy } \\
\text { Combination had no clear benefit in } \\
\text { overt diabetic nephropathy }\end{array}$ \\
\hline
\end{tabular}

Abbreviations: ACE, angiotensin-converting enzyme; ARB, angiotensin receptor blocker; MI, myocardial infarction; HF, heart failure; LVD, left ventricular dysfunction; BP, blood pressure; $A E$, adverse event; $M A U$, microalbuminuria; UACR, urinary albumin/creatinine ratio; $C V$, cardiovascular; UAER, urinary albumin excretion rate; $A E s$, adverse events; SCr, serum creatinine; ESRD, end stage renal disease; eGFR, estimated glomerular filtration rate. 
monotherapy in patients with diabetes $(P \leq 0.01) .{ }^{38}$ In healthy volunteers, therapeutic doses of aliskiren produced long-lasting increases in renal plasma flow, the magnitude of which far exceeded that of either the use of an ACE inhibitor or an ARB. Accompanying the increased renal plasma flow was a significant increase in natriuresis, indicating more effective RAAS blockade.$^{39}$ In addition, results of two recent studies show the enhanced renoprotective effects of aliskiren when combined with maximal ARB treatment in type 2 diabetes, independent of any additional BP-lowering effects. ${ }^{20,40}$ When aliskiren $(150 \mathrm{mg}$ daily for 3 months, then $300 \mathrm{mg}$ daily for 3 months) was added to once-daily losartan $100 \mathrm{mg}$ in 599 patients in the AVOID study, the mean urinary/albumin creatinine ratio was reduced by an additional $20 \%$ relative to losartan-only (placebo group) treatment $(P<0.001)$, with only a small difference in BPlowering (an additional $2 / 1 \mathrm{mmHg}$ lower).$^{20}$ Adverse event profiles were similar between aliskiren/losartan and losartan alone. In the second study, placebo, aliskiren $300 \mathrm{mg}$ once daily, irbesartan $300 \mathrm{mg}$ once daily, or the combination of aliskiren/irbesartan were directly compared for 2-month treatment periods in a $4 \times 4$ crossover design in 26 patients. ${ }^{40}$ Compared with the rates for placebo, albuminuria and albumin fractional clearance rates were reduced $58 \%$ and $46 \%$ with irbesartan, $48 \%$ and $56 \%$ with aliskiren, and $71 \%$ and $67 \%$ with the combination $(P \leq 0.028$ and $P=0.001$ versus either monotherapy), respectively.

The effects of aliskiren on surrogate markers of cardiovascular disease when combined with ACE inhibitors or ARBs have been examined in at least two studies. ${ }^{41,42}$ The ALOFT study enrolled 302 patients with heart failure and hypertension who were already receiving stable doses of ACE inhibitors or ARBs and $\beta$-blockers. Patients were treated with aliskiren $150 \mathrm{mg}$ or placebo daily for 3 months. ${ }^{41}$ The primary efficacy end point in the study was the between-treatment levels of plasma N-terminal-pro-brain natriuretic peptide (NT-proBNP), a neurohormone biomarker that forecasts an increased risk for events in heart failure (HF) patients. ${ }^{36} \mathrm{At}$ the end of the study period, mean plasma NT-proBNP levels were elevated by $762 \mathrm{pg} / \mathrm{mL}$ with placebo but decreased significantly by $244 \mathrm{pg} / \mathrm{mL}$ with aliskiren $(P=0.0106)$. Urinary aldosterone (aldosterone is a downstream component of the RAAS cascade and urinary excretion is therefore a measure of the neurohormonal effect of aliskiren) decreased $9.24 \mathrm{nmol} / \mathrm{d}$ with aliskiren and $6.96 \mathrm{nmol} / \mathrm{d}$ with placebo $(P=0.0150)$, with no difference in plasma aldosterone or BP between groups. In the second study, the ALLAY trial, ${ }^{42} 465$ hypertensive patients with left ventricular hypertrophy (LVH; left ven- tricular wall thickness $\geq 13 \mathrm{~mm}$ ) and a body mass index $>25 \mathrm{~kg} / \mathrm{m}^{2}$ were recruited. Patients were randomly assigned to receive 9 months of treatment with once-daily aliskiren $300 \mathrm{mg}$, losartan $100 \mathrm{mg}$, or a combination of both doses. If a study patient was receiving an ACE inhibitor or an ARB, they underwent a 3-month washout period prior to treatment. Left ventricular mass index was significantly reduced from baseline with losartan $\left(4.8 \mathrm{~g} / \mathrm{m}^{2} ; 4.7 \%\right)$, aliskiren $\left(4.9 \mathrm{~g} / \mathrm{m}^{2}\right.$; $5.4 \%)$, and the combination $\left(5.8 \mathrm{~g} / \mathrm{m}^{2} ; 6.4 \% ; P<0.0001\right.$ for each treatment group); differences between the combination and losartan monotherapy were not significant $(P=0.52)$. Blood pressure reductions were similar between groups. None of these studies showed any safety concerns with the combination of aliskiren plus an ACE inhibitor or an ARB, compared with monotherapy. Specifically, there were no differences in adverse events, including renal dysfunction, hyperkalemia, and discontinuation due to adverse events, including patients at risk for renal events (ie, with renal impairment and diabetes). Frequency of cough was less with the combination of aliskiren/ramipril (1.8\%) than with ramipril monotherapy (4.7\%) in the 8 -week hypertension study ${ }^{38}$ though this difference was not significant $(P=0.08)$.

\section{Uniqueness of DRI-based combinations}

When an ACE inhibitor and an ARB are combined, each signals a large reactive increase in PRA. Conversely, a DRI-based combination therapy buffers the ACE inhibitor or ARB-induced increases in PRA such that the net effect on PRA is an approximate $50 \%$ reduction $^{43}$ (Figures 2

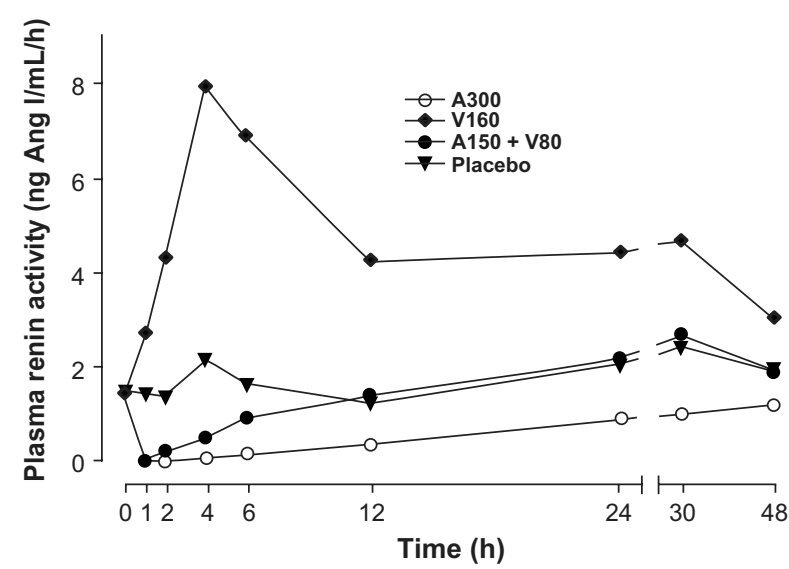

Figure 2 Time course of plasma renin activity in normotensive volunteers after administration of aliskiren $300 \mathrm{mg}$ (open circles), valsartan $160 \mathrm{mg}$ (diamonds), aliskiren $150 \mathrm{mg}$ plus valsartan $80 \mathrm{mg}$ (closed circles), and placebo (triangles). Reprinted with permission from Azizi M, Ménard J, Bissery A, et al. Pharmacologic demonstration of the synergistic effects of a combination of the renin inhibitor aliskiren and the ATI receptor antagonist valsartan on the angiotensin II-renin feedback interruption. J Am Soc Nephrol. 2004;15(I2):3I26-3133.44 Copyright (C) 2004 American Society of Nephrology.

Notes: $A$, aliskiren; $V$, valsartan. 


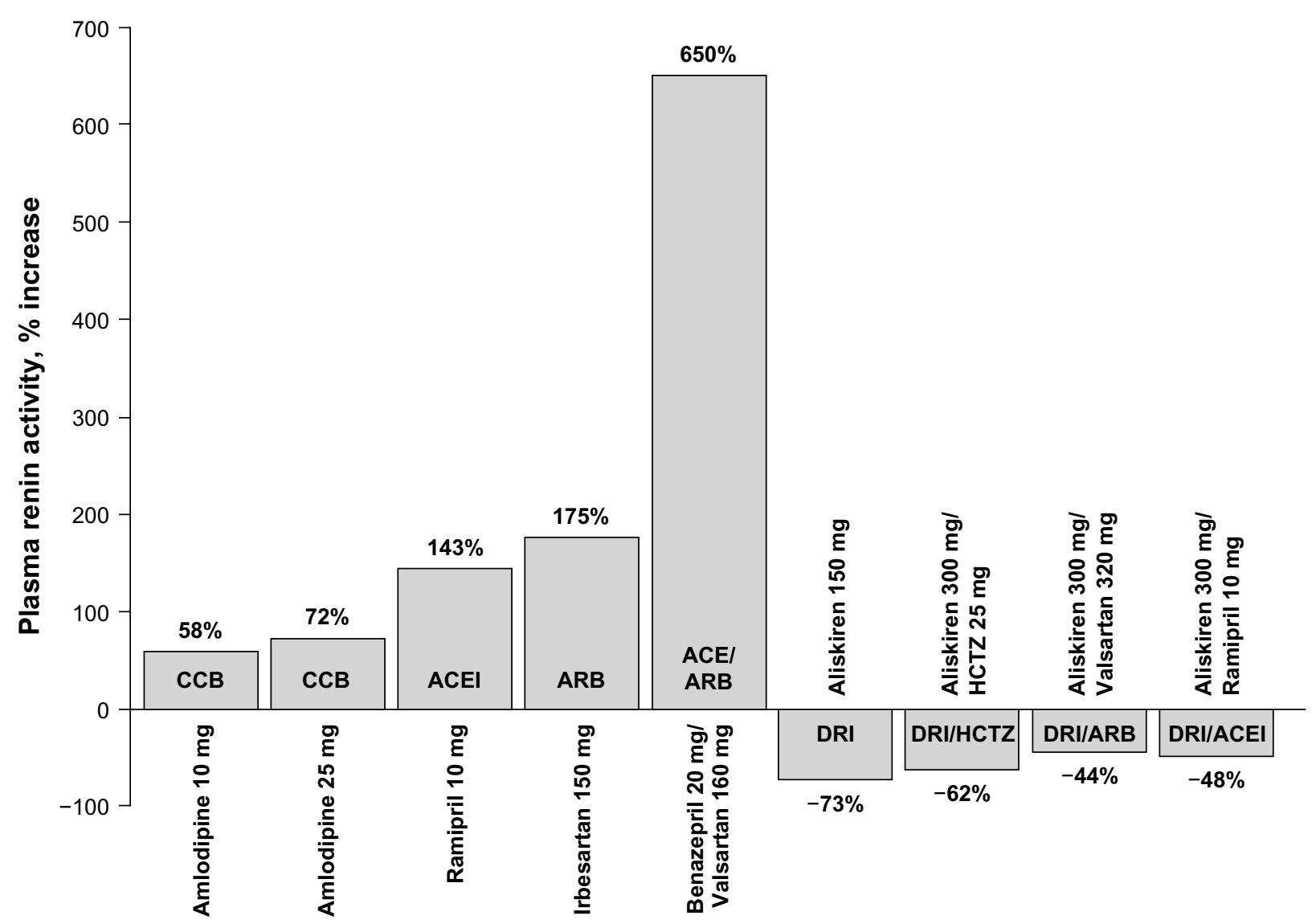

Figure 3 Effects of antihypertensive agents on plasma renin activity in patients with hypertension. ${ }^{37,38,45,60-62}$

Notes: CCB, calcium channel blocker; HCTZ, hydrochlorothiazide; ACEI, angiotensin-converting enzyme inhibitor; ARB, angiotensin receptor blocker; DRI direct renin inhibitor.

and 3). ${ }^{37,43-45}$ Reductions in PRA with aliskiren are sustained over 26 weeks of treatment and persist 4 weeks after discontinuation. ${ }^{45}$ Suppression of PRA with aliskiren monotherapy and diminution of ACE inhibitor-induced and ARB-induced increases in PRA distinguishes DRI's mechanism of action from other RAAS inhibitors. Teaming aliskiren with an ARB functionally blocks the RAAS at the first and rate-limiting step and final receptor; this complementary mechanism provides significant reductions in PRA, angiotensin I, angiotensin II, and aldosterone. ${ }^{46}$ Theoretically, any angiotensin I that is formed despite aliskiren treatment will be converted to angiotensin II and then bind at the unoccupied $\mathrm{AT}_{2}$ receptor, eliciting favorable effects.

Combining a DRI with an ACE inhibitor blocks sequential steps in the RAAS cascade. Angiotensin I that is formed despite aliskiren treatment will be inhibited from conversion to angiotensin II by the ACE inhibitor. Angiotensin II that might be formed despite this dual blockade would bind and activate either AT receptor. Bradykinin potentiation will occur because of ACE inhibition. With either DRI combina- tion, PRA is suppressed and formation of angiotensin I is greatly reduced, thus providing less substrate to drive escape pathways.

\section{Aliskiren plus valsartan}

The combination of aliskiren and the ARB valsartan was recently approved as a single-pill combination (SPC). Results of several studies support the BP-lowering effectiveness of combination therapy with these agents. In a study involving 1797 patients with mean sitting DBP between 95 and $109 \mathrm{mmHg}$ and 8-hour daytime ambulatory $\mathrm{DBP} \geq 90 \mathrm{mmHg}$, sitting $\mathrm{SBP} / \mathrm{DBP}$ was reduced by $17.2 / 12.2 \mathrm{mmHg}$ with once-daily aliskiren $300 \mathrm{mg} /$ valsartan $320 \mathrm{mg}$, by 13.0/9.0 $\mathrm{mmHg}$ with aliskiren $300 \mathrm{mg}$, by $12.8 / 9.7 \mathrm{mmHg}$ with valsartan $320 \mathrm{mg}$, and by $4.6 / 4.1 \mathrm{mmHg}$ with placebo after 8 weeks of treatment $(P<0.0001$ for combination versus monotherapy or placebo). ${ }^{47}$ In a subset of 581 patients with stage 2 hypertension ( $\mathrm{SBP} \geq 160 \mathrm{mmHg}$ ) from this study, BP reductions were even more pronounced, in favor of the combination treatment, with mean reductions in 
SBP/DBP of $22.5 / 11.4 \mathrm{mmHg}$ with the combination compared with 17.3/8.9 mmHg with aliskiren, $15.3 / 8.3 \mathrm{mmHg}$ with valsartan, and $7.9 / 3.7 \mathrm{mmHg}$ with placebo $(P \leq 0.05$ for comparisons with monotherapy or placebo). ${ }^{48}$ In a 6-month open-label study of 601 patients with hypertension (defined as having a mean sitting DBP between 90 and $109 \mathrm{mmHg}$ ), BP reductions were sustained with continued treatment. Mean SBP/DBP was reduced from baseline by 22.3/14.4 mmHg with once-daily aliskiren $300 \mathrm{mg} /$ valsartan $320 \mathrm{mg} .{ }^{49}$

The combination of maximal dose $(300 \mathrm{mg} / 320 \mathrm{mg})$ aliskiren/valsartan exhibited a safety and tolerability profile similar to that of monotherapy with either agent. In the 8-week study involving 1797 hypertensive patients, ${ }^{47}$ adverse events and laboratory abnormalities occurred to a similar degree among all treatment groups. Headache was the main adverse event reported with the combination (reported in $4 \%$ of patients), which was less than with valsartan $(5 \%)$ and placebo $(9 \%)$. The proportion of patients experiencing increases in clinically relevant laboratory values is shown in Table 3. Overall, few patients experienced increases in serum potassium, creatinine, and blood urea nitrogen levels during treatment. In addition, in patients with elevated serum potassium levels $>5.5 \mathrm{mmol} / \mathrm{L}$ at any time after baseline, serum potassium values returned to normal in 13 of 18 patients $(72 \%)$, without necessitating treatment discontinuation. During the 6-month open-label study, ${ }^{49}$ postbaseline serum potassium values $>5.5 \mathrm{mmol} / \mathrm{L}$ were infrequent and tended to be transient. Only two patients in this 6-month study $(0.3 \%)$ who received aliskiren/valsartan plus hydrochlorothiazide (HCTZ) were discontinued from treatment as a result of hyperkalemia.

\section{Role of aliskiren/valsartan in the hypertension therapeutic armamentarium}

Based on the established efficacy and safety profile of aliskiren/valsartan, this SPC is attractive for first-line use in the treatment of hypertension for those patients who have diabetes or who are at high risk for cardiovascular disease and are not likely to achieve BP goals with monotherapy, or as a second-line treatment for patients who have not achieved BP control with either an ACE inhibitor or ARB alone. In an 8-week comparative trial, ${ }^{50}$ once-daily aliskiren $300 \mathrm{mg} /$ valsartan $320 \mathrm{mg}$ provided comparable reductions to once-daily valsartan $160 \mathrm{mg} / \mathrm{HCTZ} 12.5 \mathrm{mg}$, another SPC that can be used for initial and second-line treatment for hypertension. SPCs provide an attractive treatment choice because they can improve patient adherence to hypertension treatment, compared with administration of two separate agents. ${ }^{51,52}$

The effects of aliskiren combined with another RAAS agent on various surrogate end points in the AVOID, ALOFT, and ALLAY studies (proteinuria, NT-proBNP, LVH) suggest that aliskiren-based combinations may confer incremental vasculoprotective effects that are not accounted for by BP reductions alone and, therefore, may be particularly appealing for treatment of hypertension in patients with diabetes, kidney disease, or the metabolic syndrome..$^{26,41,42,53}$ More long-term data are needed to confirm its efficacy and safety in these patient populations. Moreover, the importance of neurohormonal activation in cardiovascular disease, and more specifically, the prognostic role of increased PRA with cardiovascular disease, signal a potential role for aliskiren in this regard and support the evaluation of aliskiren/ARB combinations in

Table 3 Laboratory abnormalities occurring during treatment with placebo, aliskiren $300 \mathrm{mg}$ daily, valsartan $320 \mathrm{mg}$ daily, or the combination of aliskiren $300 \mathrm{mg} / \mathrm{valsartan} 320 \mathrm{mg}$ : results from an 8-week randomized, double-bind, placebo-controlled study and a 6-month, open-label study in patients with hypertension ${ }^{47,49}$

\begin{tabular}{|c|c|c|c|c|c|c|}
\hline \multirow[t]{3}{*}{ Laboratory abnormality } & \multicolumn{6}{|c|}{ Number (\%) of patients } \\
\hline & \multicolumn{4}{|c|}{ 8-week study ${ }^{47}$} & \multicolumn{2}{|c|}{ 6-month, open-label study ${ }^{49}$} \\
\hline & $\begin{array}{l}\text { Placebo } \\
n=458\end{array}$ & $\begin{array}{l}\text { Aliskiren } \\
n=437\end{array}$ & $\begin{array}{l}\text { Valsartan } \\
n=455\end{array}$ & $\begin{array}{l}\text { Aliskiren/valsartan } \\
\mathrm{n}=446\end{array}$ & $\begin{array}{l}\text { Aliskiren/valsartan } \\
\mathrm{n}=396\end{array}$ & $\begin{array}{l}\text { Aliskiren/valsartan/HCTZ } \\
n=588\end{array}$ \\
\hline \multicolumn{7}{|l|}{ Potassium } \\
\hline$<3.5 \mathrm{mmol} / \mathrm{L}$ & $17(4)$ & II (3) & $20(4)$ & $12(3)$ & $6(1.5)$ & $13(6.8)$ \\
\hline$>5.5 \mathrm{mmol} / \mathrm{L}$ & $12(3)$ & $7(2)$ & $7(2)$ & $18(4)$ & $10(2.5)$ & $2(1.0)$ \\
\hline$\geq 6.5 \mathrm{mmol} / \mathrm{L}$ & $6(1)$ & $4(1)$ & $5(1)$ & $2(0.5)$ & $\mathrm{I}(0.3)$ & 0 \\
\hline Creatinine $>176.8 \mu \mathrm{mol} / \mathrm{L}$ & 0 & I $(0.2)$ & $2(0.4)$ & $4(0.9)$ & $\mathrm{I}(0.3)$ & $\mathrm{I}(0.5)$ \\
\hline Blood urea nitrogen & 0 & $\mathrm{I}(0.2)$ & $\mathrm{I}(0.2)$ & 0 & $\mathrm{I}(0.3)$ & $2(1.0)$ \\
\hline$>14.3 \mathrm{mmol} / \mathrm{L}$ & & & & & & \\
\hline
\end{tabular}

Abbreviation: HCTZ, hydrochlorothiazide (up to $25 \mathrm{mg}$ daily). 
Table 4 Cardiovascular morbidity and mortality outcome studies with aliskiren in the ASPIRE HIGHER program

\begin{tabular}{|c|c|c|c|c|c|}
\hline Study & Patients & $\mathbf{n}$ & Intervention & Primary outcome & $\begin{array}{l}\text { Planned } \\
\text { follow-up }\end{array}$ \\
\hline ALTITUDE & $\begin{array}{l}\text { Type } 2 \text { diabetes and at high } \\
\text { risk for fatal and nonfatal } \\
\text { cardiorenal events }\end{array}$ & 8600 & $\begin{array}{l}\text { Aliskiren } 300 \mathrm{mg} \text { or placebo } \\
\text { on top of conventional } \\
\text { treatment (ACE inhibitor or } \\
\text { ARB plus others) }\end{array}$ & $\begin{array}{l}\text { Time to first event of CV death, } \\
\text { resuscitated sudden death, MI, stroke, } \\
\text { unplanned } \mathrm{HF} \text { hospitalization, } \\
\text { ESRD, renal death, doubling of } \mathrm{SCr} \\
\text { sustained for } \geq \mathrm{I} \text { month }\end{array}$ & 4 years \\
\hline ATMOSPHERE & Chronic HF & 7041 & $\begin{array}{l}\text { Aliskiren } 300 \mathrm{mg} \text {, enalapril } \\
10 \mathrm{mg} \text {, or a combination }\end{array}$ & $\begin{array}{l}\text { Time to first event of } \mathrm{CV} \text { death or } \mathrm{HF} \\
\text { hospitalization }\end{array}$ & 4 years \\
\hline ASTRONAUT & Hospitalized for worsening HF & 1782 & $\begin{array}{l}\text { Aliskiren } 300 \mathrm{mg} \text { or placebo } \\
\text { on top of standard therapy }\end{array}$ & $\begin{array}{l}\text { Time to first occurrence of } \mathrm{CV} \text { death } \\
\text { or HF rehospitalization within } 6 \text { months }\end{array}$ & 6 months \\
\hline APOLLO & $\begin{array}{l}\text { Elderly patients with normal } \\
\text { to high } \mathrm{BP} \text { and high } \mathrm{CV} \text { risk }\end{array}$ & & Study in development & & \\
\hline
\end{tabular}

Abbreviations: ACE, angiotensin converting enzyme; ARB, angiotensin receptor blocker; CV, cardiovascular; MI, myocardial infarction; HF, heart failure; ESRD, end stage renal disease; $\mathrm{SCr}$, serum creatinine; $\mathrm{BP}$, blood pressure.

outcomes studies. In addition, aliskiren either by itself or in combination with the ARB valsartan has been shown to have a potential benefit on reducing urinary aldosterone levels. ${ }^{47}$ This mineralocorticoid hormone, aldosterone, is associated with the development of not only hypertension, but of cardiovascular and renal diseases as well..$^{54,55}$ In addition to having a hemodynamic effect, aldosterone is associated with inflammation, platelet aggregation, hypertrophy, and fibrosis. ${ }^{56,57}$ Drugs such as eplerenone (a spironolactone derivative) that attenuate the activity of aldosterone have been shown to reduce the morbidity and mortality associated with heart failure and postMI. ${ }^{54}$ Therefore, an incremental reduction in aldosterone, by combining a DRI with an ACE-inhibitor or ARB, is expected to translate into organ protection and might explain the benefits observed to date in heart failure, diabetes mellitus associated nephropathy as well as LVH. ${ }^{22,47,58}$ The ASPIRE HIGHER program was undertaken to evaluate potential cardiorenal effects of aliskiren over a spectrum of conditions in 14 different studies involving more than 35,000 patients. ${ }^{59}$ To date, this is the largest and most comprehensive cardiorenal program undertaken to evaluate a particular pharmacologic intervention. Three of the studies evaluating surrogate end points have been discussed herein (AVOID, ALLAY, and ALOFT) and favorable effects of adding aliskiren to standard treatment have been found. The ASPIRE HIGHER program also includes four morbidity and mortality trials (Table 4), which were designed with the aim of improving the standard of care by adding a DRI to current best practice and also to elucidate the role of DRI therapy in situations in which there is no established effective standard of care. Results from the first of these trials (ALTITUDE) are expected in 2012. ${ }^{58}$

\section{Conclusion}

ACE inhibitors and ARBs have been valuable in improving outcomes in cardiovascular and renal diseases; however, there remains significant residual risk of cardiovascular events even when these agents are used, which could be attributable to incomplete blockade of the RAAS. In fact, ACE inhibitors and ARBs silence negative feedback control of RAAS and accelerate the production of angiotensin I. For this reason, direct renin inhibition has long been considered a possible therapeutic mechanism for hypertension and cardiovascular disease. The availability of aliskiren for the treatment of hypertension signals the beginning of a new era in RAAS blockade. Aliskiren's unique mechanism of action and ability to buffer PRA justifies its availability as an SPC with valsartan. Initial studies in patients with diabetic nephropathy, LVH, and HF have shown promising effects on surrogate markers and long-term outcome studies are under way; results are eagerly awaited. In the meantime, the combination of aliskiren plus valsartan affords clinicians an SPC agent with demonstrated superior RAAS protection and safe and effective BP lowering, making the combination an important addition to the antihypertensive repertoire.

\section{Acknowledgments}

Editorial assistance was provided by Neal Azrolan, $\mathrm{PhD}$, and Jacqueline Bailey, PharmD, of Oxford PharmaGenesis and was funded by Novartis Pharmaceuticals Corporation. Dr Epstein had full control over the contents of the manuscript.

\section{Disclosure}

Dr Epstein has received research grants or consulting/speaking honoraria from Novartis Pharmaceuticals Corporation, Forest Laboratories Inc., GlaxoSmithKline, and sanofi-aventis. 


\section{References}

1. Giles TD, Materson BJ, Cohn JN, Kostis JB. Definition and classification of hypertension: an update. J Clin Hypertens (Greenwich). 2009;11(11):611-614.

2. Lewington S, Clarke R, Qizilbash N, Peto R, Collins R. Age-specific relevance of usual blood pressure to vascular mortality: a meta-analysis of individual data for one million adults in 61 prospective studies. Lancet. 2002;360(9349):1903-1913.

3. Vasan RS, Larson MG, Leip EP, et al. Impact of high-normal blood pressure on the risk of cardiovascular disease. $N$ Engl J Med. 2001;345(18):1291-1297.

4. Douglas JG, Bakris GL, Epstein M, et al. Management of high blood pressure in African Americans: consensus statement of the Hypertension in African Americans Working Group of the International Society on Hypertension in Blacks. Arch Intern Med. 2003;163(5):525-541.

5. Chobanian AV, Bakris GL, Black HR, et al. Seventh report of the Joint National Committee on Prevention, Detection, Evaluation, and Treatment of High Blood Pressure. Hypertension. 2003;42(6):1206-1252.

6. Ong KL, Cheung BM, Man YB, Lau CP, Lam KS. Prevalence, awareness, treatment, and control of hypertension among United States adults 1999-2004. Hypertension. 2007;49(1):69-75.

7. Wong ND, Lopez VA, L'Italien G, Chen R, Kline SE, Franklin SS. Inadequate control of hypertension in US adults with cardiovascular disease comorbidities in 2003-2004. Arch Intern Med. 2007; 167(22):2431-2436.

8. Cushman WC, Ford CE, Cutler JA, et al. Success and predictors of blood pressure control in diverse North American settings: the antihypertensive and lipid-lowering treatment to prevent heart attack trial (ALLHAT). $J$ Clin Hypertens (Greenwich). 2002;4(6):393-404.

9. Dahlöf B, Sever PS, Poulter NR, et al. Prevention of cardiovascular events with an antihypertensive regimen of amlodipine adding perindopril as required versus atenolol adding bendroflumethiazide as required, in the Anglo-Scandinavian Cardiac Outcomes Trial-Blood Pressure Lowering Arm (ASCOT-BPLA): a multicentre randomised controlled trial. Lancet. 2005;366(9489):895-906.

10. Wright JT Jr, Bakris G, Greene T, et al. Effect of blood pressure lowering and antihypertensive drug class on progression of hypertensive kidney disease: results from the AASK trial. JAMA. 2002; 288(19):2421-2431.

11. Mancia G, Laurent S, Agabiti-Rosei E, et al. Reappraisal of European guidelines on hypertension management: a European Society of Hypertension Task Force document. J Hypertens. 2009;27:2121-2158.

12. Kjeldsen SE, Weber M, Oparil S, Jamerson KA. Combining RAAS and calcium channel blockade: ACCOMPLISH in perspective. Blood Press. 2008;17(5-6):260-269.

13. Jamerson K, Weber MA, Bakris GL, et al. Benazepril plus amlodipine or hydrochlorothiazide for hypertension in high-risk patients. $N$ Engl J Med. 2008;359(23):2417-2428.

14. Weber MA, Julius S, Kjeldsen SE, et al. Blood pressure dependent and independent effects of antihypertensive treatment on clinical events in the VALUE Trial. Lancet. 2004;363(9426):2049-2051.

15. Staessen JA, Thijisq L, Fagard R, et al. Effects of immediate versus delayed antihypertensive therapy on outcome in the Systolic Hypertension in Europe Trial. J Hypertens. 2004;22(4):847-857.

16. Dzau VJ, Antman EM, Black HR, et al. The cardiovascular disease continuum validated: clinical evidence of improved patient outcomes part I: pathophysiology and clinical trial evidence (risk factors through stable coronary artery disease). Circulation. 2006;114(25): 2850-2870.

17. Dzau VJ. Theodore Cooper Lecture: Tissue angiotensin and pathobiology of vascular disease: a unifying hypothesis. Hypertension. 2001;37(4):1047-1052.

18. Schmitz O, Hansen HE, Orskov H, Mogensen CE, Posborg Petersen V. End-state renal failure in diabetic nephropathy: pathophysiology and treatment. Blood Purif. 1985;3(1-3):120-139.

19. Brenner BM, Cooper ME, de Zeeuw D, et al. Effects of losartan on renal and cardiovascular outcomes in patients with type 2 diabetes and nephropathy. N Engl J Med. 2001;345(12):861-869.
20. Parving HH, Persson F, Lewis JB, Lewis EJ, Hollenberg NK. Aliskiren combined with losartan in type 2 diabetes and nephropathy. $N$ Engl J Med. 2008;358(23):2433-2446.

21. Alderman MH, Ooi WL, Cohen H, Madhavan S, Sealey JE, Laragh JH. Plasma renin activity: a risk factor for myocardial infarction in hypertensive patients. Am J Hypertens. 1997;10(1):1-8.

22. Verma S, Gupta M, Holmes DT, et al. 2009. Plasma renin activity is associated with increased cardiovascular events and mortality in the HOPE study. Circulation. 120:S453. Abstract 1134.

23. Bair TL, May HT, Prescott MF, et al. 2009. Association between baseline levels of plasma renin activity and risk of cardiovascular events. J Am Coll Cardiol. 53(10 Suppl A):A383. Abstract 1028-12.

24. Vogt B, Burnier M. Aldosterone and cardiovascular risk. Curr Hypertens Rep. 2009;11(6):450-455.

25. Doulton TW. ACE inhibitor-angiotensin receptor blocker combinations: a clinician's perspective. Mini Rev Med Chem. 2006;6(5):491-497.

26. Epstein BJ, Smith SM, Choksi R. Recent changes in the landscape of combination RAS blockade. Expert Rev Cardiovasc Ther. 2009; 7(11):1373-1384.

27. Yoneda T, Takeda Y, Usukura M, et al. Aldosterone breakthrough during angiotensin II receptor blockade in hypertensive patients with diabetes mellitus. Am J Hypertens. 2007;20(12):1329-1333.

28. Bomback AS, Klemmer PJ. The incidence and implications of aldosterone breakthrough. Nat Clin Pract Nephrol. 2007;3(9):486-492.

29. Riccioni G, Vitulano N, D’Orazio N, Bellocci F. Aliskiren, the first approved renin inhibitor: Clinical application and safety in the treatment of hypertension. Adv Ther. 2009;26(7):700-710.

30. Doulton TW, He FJ, MacGregor GA. Systematic review of combined angiotensin-converting enzyme inhibition and angiotensin receptor blockade in hypertension. Hypertension. 2005;45(5):880-886.

31. Yusuf S, Teo KK, Pogue J, et al. Telmisartan, ramipril, or both in patients at high risk for vascular events. N Engl J Med. 2008; 358(15): 1547-1559.

32. Mann JF, Schmieder RE, McQueen M, et al. Renal outcomes with telmisartan, ramipril, or both, in people at high vascular risk (the ONTARGET study): a multicentre, randomised, double-blind, controlled trial. Lancet. 2008;372(9638):547-553.

33. Hollenberg NK, Parving HH, Viberti G, et al. Albuminuria response to very high-dose valsartan in type 2 diabetes mellitus. J Hypertens. 2007;25(9):1921-1926.

34. Atlas SA. The renin-angiotensin aldosterone system: pathophysiological role and pharmacologic inhibition. J Manag Care Pharm. 2007; 13(8 Suppl S-b):S9-S20.

35. Rouleau JL, Packer M, Moye L, et al. Prognostic value of neurohumoral activation in patients with an acute myocardial infarction: effect of captopril. J Am Coll Cardiol. 1994;24(3):583-591.

36. Latini R, Masson S, Anand I, et al. The comparative prognostic value of plasma neurohormones at baseline in patients with heart failure enrolled in Val-HeFT. Eur Heart J. 2004;25(4):292-299.

37. O‘Brien E, Barton J, Nussberger J, et al. Aliskiren reduces blood pressure and suppresses plasma renin activity in combination with a thiazide diuretic, an angiotensin-converting enzyme inhibitor, or an angiotensin receptor blocker. Hypertension. 2007;49(2):276-284.

38. Uresin Y, Taylor AA, Kilo C, et al. Efficacy and safety of the direct renin inhibitor aliskiren and ramipril alone or in combination in patients with diabetes and hypertension. J Renin Angiotensin Aldosterone Syst. 2007;8(4):190-198.

39. Fisher ND, Jan Danser AH, Nussberger J, Dole WP, Hollenberg NK. Renal and hormonal responses to direct renin inhibition with aliskiren in healthy humans. Circulation. 2008;117(25):3199-3205.

40. Persson F, Rossing P, Reinhard H, et al. Renal effects of aliskiren compared to and in combination with irbesartan in patients with type 2 diabetes, hypertension and albuminuria. Diabetes Care. 2009;32(10): 1873-1879.

41. McMurray JJ, Pitt B, Latini R, et al. Effects of the oral direct renin inhibitor aliskiren in patients with symptomatic heart failure. Circ Heart Fail. 2008;1:17-24. 
42. Solomon SD, Appelbaum E, Manning WJ, et al. Effect of the direct renin inhibitor aliskiren, the angiotensin receptor blocker losartan, or both on left ventricular mass in patients with hypertension and left ventricular hypertrophy. Circulation. 2009;119(4):530-537.

43. Taylor AA, Anderson DR, Arora V, et al. 2007. Renin system suppression with the oral direct renin inhibitor aliskiren administered alone or in combination: a pooled analysis of 1093 patients with hypertension. J Am Coll Cardiol. 49(9 Suppl A):370A. Abstract $1014-1170$.

44. Azizi M, Ménard J, Bissery A, et al. Pharmacologic demonstration of the synergistic effects of a combination of the renin inhibitor aliskiren and the AT1 receptor antagonist valsartan on the angiotensin II-renin feedback interruption. J Am Soc Nephrol. 2004;15(12):3126-3133.

45. Andersen K, Weinberger MH, Constance CC, et al. Comparative effects of aliskiren-based and ramipril-based therapy on the renin system during long-term (6 months) treatment and withdrawal in patients with hypertension. J Renin Angiotensin Aldosterone Syst. 2009;10(3):157-167.

46. Valturna (aliskiren and valsartan, USP) Tablets [prescribing information]. 2010. East Hanover, NJ: Novartis Pharmaceuticals Corporation.

47. Oparil S, Yarows SA, Patel S, Fang H, Zhang J, Satlin A. Efficacy and safety of combined use of aliskiren and valsartan in patients with hypertension: a randomised, double-blind trial. Lancet. 2007;370(9583):221-229.

48. Yarows SA, Oparil S, Patel S, Fang H, Zhang J. Aliskiren and valsartan in stage 2 hypertension: subgroup analysis of a randomized, doubleblind study. Adv Ther. 2008;25(12):1288-1302.

49. Chrysant SG, Murray AV, Hoppe UC, et al. Long-term safety, tolerability and efficacy of aliskiren in combination with valsartan in patients with hypertension: a 6-month interim analysis. Curr Med Res Opin. 2008;24(4):1039-1047.

50. Pool JL, Schmieder RE, Azizi M, et al. Aliskiren, an orally effective renin inhibitor, provides antihypertensive efficacy alone and in combination with valsartan. Am J Hypertens. 2007;20(1):11-20.

51. Bangalore S, Kamalakkannan G, Parkar S, Messerli FH. Fixed-dose combinations improve medication compliance: a meta-analysis. $\mathrm{Am} \mathrm{J}$ Med. 2007;120(8):713-719.

52. Burnier M, Brown RE, Ong SH, Keskinaslan A, Khan ZM. Issues in blood pressure control and the potential role of single-pill combination therapies. Int J Clin Pract. 2009;63(5):790-798.

53. Riche DM, Minor DS, Holdiness AS, East HE. An issue of dependence: implications from the Aliskiren in the Evaluation of Proteinuria in Diabetes (AVOID) trial. J Clin Hypertens (Greenwich). 2009;11(2):89-93.

54. Pitt B, Remme W, Zannad F, et al. Eplerenone, a selective aldosterone blocker, in patients with left ventricular dysfunction after myocardial infarction. N Engl J Med. 2003;348(14):1309-1321.

55. Pitt B, Zannad F, Remme WJ, et al. The effect of spironolactone on morbidity and mortality in patients with severe heart failure. Randomized Aldactone Evaluation Study Investigators. $N$ Engl $J$ Med. 1999;341(10):709-717.

56. Bauersachs J, Heck M, Fraccarollo D, et al. Addition of spironolactone to angiotensin-converting enzyme inhibition in heart failure improves endothelial vasomotor dysfunction: role of vascular superoxide anion formation and endothelial nitric oxide synthase expression. $J \mathrm{Am}$ Coll Cardiol. 2002;39(2):351-358.

57. Rajagopalan S, Duquaine D, King S, Pitt B, Patel P. Mineralocorticoid receptor antagonism in experimental atherosclerosis. Circulation. 2002;105(18):2212-2216.

Vascular Health and Risk Management

\section{Publish your work in this journal}

Vascular Health and Risk Management is an international, peerreviewed journal of therapeutics and risk management, focusing on concise rapid reporting of clinical studies on the processes involved in the maintenance of vascular health; the monitoring, prevention and treatment of vascular disease and its sequelae; and the involvement of
58. Parving HH, Brenner BM, McMurray JJ, et al. Aliskiren Trial in Type 2 Diabetes Using Cardio-Renal Endpoints (ALTITUDE): rationale and study design. Nephrol Dial Transplant. 2009;24(5):1663-1671.

59. Lee HY, Oh BH. Cardio-renal protection with aliskiren, a direct renin inhibitor, in the ASPIRE HIGHER program. Expert Rev Cardiovasc Ther. 2009;7(3):251-257.

60. Loriga G, Vidili G, Ruggenenti P, Faedda R, Sanna M, Satta AE. Renal hemodynamics and renoprotection. Nephron Clin Pract. 2008;110(4):c213-c219.

61. Drummond W, Munger MA, Rafique EM, Maboudian M, Khan M, Keefe DL. Antihypertensive efficacy of the oral direct renin inhibitor aliskiren as add-on therapy in patients not responding to amlodipine monotherapy. J Clin Hypertens (Greenwich). 2007;9(10):742-750.

62. Villamil A, Chrysant SG, Calhoun D, et al. Renin inhibition with aliskiren provides additive antihypertensive efficacy when used in combination with hydrochlorothiazide. J Hypertens. 2007;25(1):217-226.

63. Yusuf S, Sleight P, Pogue J, Bosch J, Davies R, Dagenais G. Effects of an angiotensin-converting-enzyme inhibitor, ramipril, on cardiovascular events in high-risk patients. The Heart Outcomes Prevention Evaluation Study Investigators. $N$ Engl J Med. 2000;342(3):145-153.

64. Effects of enalapril on mortality in severe congestive heart failure. Results of the Cooperative North Scandinavian Enalapril Survival Study (CONSENSUS). The CONSENSUS Trial Study Group. $N$ Engl J Med. 1987;316(23):1429-1435.

65. Effect of enalapril on survival in patients with reduced left ventricular ejection fractions and congestive heart failure. The SOLVD Investigators. N Engl J Med. 1991;325(5):293-302.

66. Cohn JN, Tognoni G. A randomized trial of the angiotensinreceptor blocker valsartan in chronic heart failure. $N$ Engl $J$ Med. 2001;345(23):1667-1675.

67. Dahlöf B, Devereux RB, Kjeldsen SE, et al. Cardiovascular morbidity and mortality in the Losartan Intervention For Endpoint reduction in hypertension study (LIFE): a randomised trial against atenolol. Lancet. 2002;359(9311):995-1003.

68. Granger CB, McMurray JJ, Yusuf S, et al. Effects of candesartan in patients with chronic heart failure and reduced left-ventricular systolic function intolerant to angiotensin-converting-enzyme inhibitors: the CHARM-Alternative trial. Lancet. 2003;362(9386):772-776.

69. Lewis EJ, Hunsicker LG, Clarke WR, et al. Renoprotective effect of the angiotensin-receptor antagonist irbesartan in patients with nephropathy due to type 2 diabetes. $N$ Engl J Med. 2001;345(12):851-860.

70. Pfeffer MA, McMurray JJ, Velazquez EJ, et al. Valsartan, captopril, or both in myocardial infarction complicated by heart failure, left ventricular dysfunction, or both. N Engl J Med. 2003;349(20):1893-1906.

71. McMurray JJ, Ostergren J, Swedberg K, et al. Effects of candesartan in patients with chronic heart failure and reduced left-ventricular systolic function taking angiotensin-converting-enzyme inhibitors: the CHARM-Added trial. Lancet. 2003;362(9386):767-771.

72. Mogensen CE, Neldam S, Tikkanen I, et al. Randomised controlled trial of dual blockade of renin-angiotensin system in patients with hypertension, microalbuminuria, and non-insulin dependent diabetes: the candesartan and lisinopril microalbuminuria (CALM) study. BMJ. 2000;321(7274):1440-1444.

73. Bakris GL, Ruilope L, Locatelli F, et al. Treatment of microalbuminuria in hypertensive subjects with elevated cardiovascular risk: results of the IMPROVE trial. Kidney Int. 2007;72(7):879-885.

metabolic disorders, particularly diabetes. This journal is indexed on PubMed Central and MedLine. The manuscript management system is completely online and includes a very quick and fair peer-review system, which is all easy to use. Visit http://www.dovepress.com/ testimonials.php to read real quotes from published authors. 